\title{
SUSTAINABLE TOURISM: RESEARCH AND REALITY
}

\section{Ralf Buckley}

Griffith University, Australia

Ralf Buckley (Director, International Centre for Ecotourism Research, Griffith University, Australian 4222, <r.buckley@griffith.edu.au>) leads Griffith University's research in sustainable tourism, currently ranked first worldwide. He has $\sim 750$ publications including 200 journal articles and a dozen books, about half in ecotourism, and has worked in $>40$ countries.

\begin{abstract}
:
Social and environmental impacts, responses and indicators are reviewed for the mainstream tourism sector worldwide, in five categories: population, peace, prosperity, pollution and protection.
\end{abstract}

Of the $\sim 5000$ relevant publications, very few attempt to evaluate the entire global tourism sector in terms which reflect global research in sustainable development. The industry is not yet close to sustainability.

The main driver for improvement is regulation rather than market measures. Some tourism advocates still use political approaches to avoid environmental restrictions, and to gain access to public natural resources.

Future research priorities include: the role of tourism in expansion of protected areas; improvement in environmental accounting techniques; and the effects of individual perceptions of responsibility in addressing climate change.

\section{Keywords:}

indicator, development, enterprise, environment, community, social. 


\section{INTRODUCTION}

Tourism researchers first turned their attention to social and environmental issues almost four decades ago (Allen, Long, Perdue, \& Kieselbach, 1988; Brougham \& Butler, 1981; Cater, 1987; Cohen, 1978; Farrell \& McLellan, 1987; Liu \& Var, 1986; Smith, 1977; Turner \& Ash, 1975; Young, 1973). Research using the specific term sustainable tourism, however, commenced barely two decades ago (May, 1991; Nash \& Butler, 1990). The first decade yielded compilations (Coccossis \& Nijkamp, 1995; Hall \& Lew, 1998; McCool \& Moisey, 2001; Stabler, 1997; Swarbrooke, 1999), and basic frameworks from backgrounds in tourism (Butler, 1999; Clarke, 1997; Hall \& Butler, 1995; Hughes, 1995; Hunter, 1997), economics (Driml \& Common, 1996; Garrod \& Fyall, 1998) and environmental management (Buckley, 1996). The second decade yielded a number of reconceptualisations, and a series of critiques including Sharpley (2000), Casagrandi and Rinaldi (2002), Gössling (2002), Liu (2003), Saarinen (2006) and Lane (2009).

As we enter a third decade, this review takes stock of progress by assessing the scope, focus and outcomes of academic research publication in sustainable tourism, against the practicalities of sustainability in the commercial tourism industry. Its basic premise is that the key issues in sustainable tourism are defined by the fundamentals of sustainability, external to the literature of tourism research. This premise relies on the axiom that both the tourism industry, and sustainability, are real-world phenomena. Therefore, this review does not attempt to deduce internally-generated research themes from analysis of bibliometric patterns in sustainable tourism publications. Instead, it constructs externally-generated themes by applying the key components of sustainability to tourism, and uses these to evaluate the sustainable tourism literature. This yields two outcomes. Firstly, it uses the results of research to assess the current sustainability of the tourism industry. Secondly, by comparing relative research effort against industry significance, it identifies priorities for future research.

This is a review specifically of the tourism research literature. Research in science, environment, resource management, global change, human health, economics and development policy is also relevant to sustainable tourism, but for reasons of space and focus, is not detailed here. The literature of tourism is large, $>150,000$ items in total, with $\sim 5,000$ relevant to sustainable tourism (CIRET, 2012). Because of space constraints, this review can cite $<250$ individual items, i.e. $<5 \%$ of the relevant literature. It largely omits topics which 
have been reviewed recently, such as water consumption and climate change (Gössling et al., 2011; Weaver, 2011). It examines the mainstream commercial tourism industry: recreation, ecotourism and responsible tourism are considered only where relevant. It first defines a framework for evaluation, under five main themes. It then compares the tourism research literature against that framework. For each theme, it summarises outcomes of all relevant research to date, supported by a representative selection of critical citations. Finally, it compares research effort and results against real-world progress and significance.

The five themes used for the evaluation framework are: population, peace, prosperity, pollution, and protection. The rationale is as follows. The fundamental concern of sustainability is that aggregate human impacts threaten the survival of humans and the ecosystem services on which they depend (Pereira, Leadley, Proença, Alkemade, \& Scharlemann, 2010; Persha, Agrawal, \& Chhatre, 2011). Impacts have grown, ultimately, because biological evolutionary pressures promote continuing human reproduction and competitive consumption. Sustainability requires modifications to human society so as to reduce its aggregate impacts. Impacts depend on: (a) the size and distribution of the global human population; (b) its social organisation, including economy, governance and civil society; and (c) the consumption, pollution, and/or protection of nature as a result of such social organisation. World population is a key predictor of current and future human impact on the planet. Peace is a global measure of successful social organisation and governance. Prosperity is a measure of economic activity, and a surrogate for per capita resource consumption. Pollution indicates increases in environmental impact. Protected areas indicate reductions.

Each of these factors can be changed through technological, individual or political means; and each of these means can generate either gains or losses in sustainability. Technological advances can reduce resource consumption and waste generation locally, even though they have increased both globally. Market-based measures can modify individual behaviour either to increase or reduce environmental footprints. Governments introduce laws, policies and incentives which can either reduce or increase pollution, environmental protection and social equity. The intentions and outcomes of any such measures are commonly difficult to deconstruct or predict. Organisations may promote measures based on individual choice or social responsibility in order to disperse opposition and forestall regulation (Beder, 1997; Buckley \& Pegas, in press; Honey, 1999; Nunez, 2007; Wagner, 2011). In the tourism sector, 
Saarinen (2006), Nelson (2010), and Yasarata, Altinay, Burns, and Okumus (2010), showed that industry advocates use the jargon of sustainability and community to strengthen power bases and legitimise current unsustainable practices.

\section{SUSTAINABLE TOURISM RESEARCH}

Research on links between tourism and population is limited. At global scale, population growth increases tourism and its impacts, but there is little evidence whether tourism influences population. At local scale, tourism can generate economic growth and population change, mainly through migration (Getz, 1986; Ghali, 1976; Gill \& Williams, 1994; Smith, 1977). Some national parks, for example, attract new migrants through tourism opportunities (Wittemeyer, Elsen, Bean, Burton, \& Brashares, 2008); but in some cases, resident populations decrease despite growth in tourism (Heberlein, Fredman, \& Vuorio, 2002).

Tourism may also have demographic effects at a more local scale. Tourism income can reduce family size by indirect mechanisms such as funding female education and reducing dependence on subsistence labour. At the same time, however, tourism may decrease infant mortality and increase longevity, by funding healthcare. Net effects of tourism on internal population growth rates, unrelated to migration, are thus unclear even at local scale.

Links between tourism and peace are also little studied. Peace dividends include social and environmental as well as economic components. Wars and terrorism decrease tourism, at least in the short term (Larson, Brun, Ogaard, \& Selstad, 2011; Llorca-Vivero, 2008; Neumayer, 2004; Spillerman \& Stecklov, 2009). Tourism may contribute to peace through improved cross-cultural understanding (International Institute for Peace through Tourism [IIPT], 2011).

The links between tourism, prosperity and sustainability are complex. At large scale, prosperity increases environmental impact. Claims that environmental protection increases with economic growth are an erroneous interpretation of development history (Buckley, 1993): the finance industries are in the richest nations, manufacturing in industrialising nations, and biological extractive industries in developing nations, but this is a pattern, not a causal chain. At local scale, in developing nations tourism wealth buys guns, fishing boats, chainsaws, livestock, and labour, with costs to conservation and equity: prosperity only 
improves sustainability if harnessed by pre-existing social institutions (Buckley, 2003a). In developed nations, tourism contributes to urban development, material consumption, and pressure on protected areas.

Distinguishing prosperity from poverty includes considerations of culture and equity, expressed in terms such as social impacts, community participation and pro-poor tourism. These are heavily studied, particularly for developing nations and indigenous peoples (Naughton-Treves, Holland, \& Brandon, 2005; Robinson, 1999; Somanathan, Prabhakar, \& Mehta, 2009; Stronza, 2001; Stronza \& Gordillo, 2008; Weaver, 2010). In the wealthier nations, there are examples from Australia (Fallon \& Kriwoken, 2003) and the USA (Ahn, Lee, \& Shafer, 2002; Choi \& Murray, 2010; Davis \& Morais, 2004; Yu, Chancellor, \& Cole, 2011).

Especially in less wealthy nations, there may often be cultural, historical and socioeconomic differences between residents and international tourists, and internal divisions within communities. Case studies are available from: Turkey (Ferhan, 2006; Tucker, 2001), Ghana (Akyeampong, 2011), Kenya (Manyara \& Jones, 2007), Botswana (Hemson, Maclennan, Mills, Johnson, \& Macdonald, 2009; Mbaiwa, 2011; Mbaiwa \& Stronza, 2010), Indonesia (Cole, 2006), Fiji (Farrelly, 2011), the Philippines (Okazaki, 2008), Papua New Guinea (Wearing, Wearing, \& McDonald, 2010) and Costa Rica (Matarrita-Cascante, Brennan, \& Luloff, 2010).

Tourism contributes to pollution of atmosphere, oceans and freshwater (Gössling, 2002; Gössling \& Schumacher, 2010; Gössling et al., 2011). In 2001, tourism had consumed 0.34\%

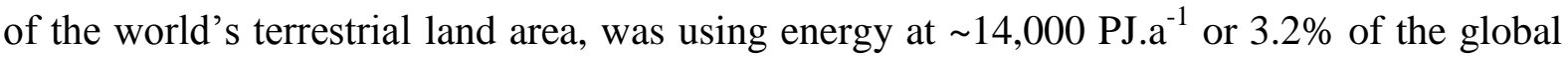
total, and had contributed $~ 5 \%$ of anthropogenic climate change (Gössling, 2002). Climate change and its links to tourism have been examined intensively over the past five years (Becken \& Patterson, 2006; Dubois \& Ceron, 2006; Gössling, 2009; Mendes \& Santos, 2008; Scott, 2011; Weaver, 2011). The industry makes unrealistic claims over emission reductions (Gössling \& Peeters, 2007), carbon offsets (Gössling et al., 2007), and carbon neutrality (Glomsrød, Wei, Liu, \& Aune, 2011; Gössling, 2009; Gössling \& Schumacher, 2010). Tourist travel continues nevertheless, because of individual desires and cultural factors (Buckley, 2011b; Cohen \& Higham, 2011; Dickinson \& Dickinson, 2006; Hamilton, Maddison, \& Tol, 2005; Hares, Dickinson, \& Wilkes, 2010; Verbeek \& Mommaas, 2008; 
Weaver, 2011), though some tourist destinations and subsectors are already affected by climate change (Buckley, 2008a; Perry, 2006; Pickering \& Buckley, 2010; Scott, McBoyle, Minogue, \& Mills, 2006).

Tourism produces direct local impacts on air, water, soil and biota; and indirect impacts from manufacture and transport of material items. Impacts derive from atmospheric emissions, solid and liquid wastes, and consumption of water, energy and materials (Aall, 2011; Buckley \& Araujo, 1997; Chan \& Lam, 2003; Charara, Cashman, Bonnell, \& Gehr, 2011; Cummings, 1997; Gössling, 2000, 2002; Smerecnik \& Andersen, 2011). In parks and natural areas there are additional impacts from vegetation damage and wildlife disturbance (Buckley, 2004; Buckley, 2011a; Liddle, 1997; Nimon, Schroter, \& Stonehouse, 1995). This is one of the most active fields in sustainable tourism research (Acevedo-Gutiérrez, Acevedo, \& Boren, 2011; Cunha, 2010; Halfwerk, Holleman, Lessells, \& Slabbekoorn, 2011; Higham \& Shelton, 2011;

Huang, Lubarsky, Teng, \& Blumstein, 2011; Kociolek, Clevenger, St. Clair, \& Proppe, 2011; Lian, Zhang, Cao, Su, \& Thirgood, 2011; Maréchal et al., 2011; Reed \& Merenlender, 2011; Remacha, Pérez-Tris, \& Delgado, 2011; Roux-Fouillet, Wipf, \& Rixen, 2011; Steven, Pickering, \& Castley, 2011; Velando \& Munilla, 2011; Wang, Li, Beauchamp, \& Jiang, 2011; Zhong, Deng, Song, \& Ding, 2011).

Private-sector approaches to sustainability such as self-regulation, corporate social responsibility, ecocertification, and destination marketing and demarketing have been promoted widely, but proved largely ineffective (Ayuso, 2007; Black \& Crabtree, 2007; Blanco, Lozano, \& Ray-Maquieira, 2009; Buckley, 2002; Buckley, 2011a; Buckley \& Pegas, in press; Choo, 2011; Claver-Cortes, Molina-Azoin, Pereira-Moliner, \& Lopez-Gamero, 2007; Erkus-Ozturk \& Eraydln, 2010; Font \& Buckley, 2001; Forsyth, 1997; Kastenholz, 2004; McKenna, Williams, \& Cooper, 2011; Priego, Najera, \& Font, 2011; Sheldon \& Park, 2011). Few tourists select sustainable products specifically (Budeanu, 2007); they expect good environmental management routinely (Mair \& Jago 2010). Industry advocates promote self-regulation to avoid government regulation (Nunez, 2007). Property developers lobby for development rights in public protected areas, but with few exceptions (Buckley, 2010), this has proved inimical to conservation.

Environmental policies, management measures and technologies can reduce many tourism 
impacts (Buckley, 2009b). Regulatory instruments provide the foundation of sustainability in tourism as in other industry sectors. Success is often limited by poor implementation, in both developed and developing nations worldwide (Berry \& Ladkin, 1997; Buckley 2008a; Buckley 2011a; Dinica 2009; Godfrey, 1995; Hall 2010; Hunter \& Shaw, 2007; Ioannides, 1995; Logar, 2010; Martin-Cejas \& Sanchez, 2010; Mycoo, 2006; Soteriou \& Coccossis, 2010; Tosun, 2001; Wall, 1993; Warnken \& Buckley, 1998; Zubair, Bowen, \& Elwin, 2010). These relatively standard and straightforward planning, regulatory and technological approaches are key to reducing the pollution and associated impacts from large-scale and mainstream tourism development in urban and peri-urban areas, and resort clusters in coastal and montane destinations.

Case studies of such approaches are widespread. There are $>35$ such studies at individual sites. Early examples include Owen, Witt, and Gammon (1993) in Wales, and Hall and Wouters (1994) in the sub- Antarctic. There are also >15 case studies focussing on subsectors rather than sites. Examples include: marine wildlife tours (Moore \& Rodger, 2010; Wilson \& Tisdell, 2001); birding festivals (Lawton \& Weaver, 2010); cruise tourism (Hritz \& Cecil, 2008), and events and conventions (Mair \& Jago, 2010; Park \& Boo, 2010). There are much larger compilations using the terminology of ecotourism (Buckley, 2003a; Gössling \& Hultman, 2006; Stronza \& Durham, 2008; Zeppel, 2006); responsible tourism (Spenceley, 2008); community tourism (Nelson, 2010; Saarinen, Becker, Manwa, \& Wilson, 2009) and conservation tourism (Buckley, 2010).

Tourism in public protected areas is heavily studied, with a focus on: visitor numbers (Buckley, 1999; Lindberg, McCool, \& Stankey, 1997; Shultis \& More, 2011); fees and concessions arrangements (Alpizar, 2006; Barborak, 2011; Buckley, 2003b; Chung, Kyle, Petrick, \& Absher, 2011; Crompton, 2011; Mmopelwa, Kgathi, \& Molefhe, 2007; Peters \& Hawkins, 2009; Reynisdottir, Song, \& Agrusa, 2008; Thur, 2010; Uyarra, Gill, \& Côté, 2010); access (Kaltenborn, Haaland, \& Sandell, 2001; McCool \& Stankey, 2001); management tools (Buckley, 1998; Buckley, 2009a; Buckley, 2009b; Eagles, McCool, \& Haynes, 2002); and interpretation (Ballantyne, Packer, \& Hughes, 2009; Ballantyne, Packer, \& Sutherland, 2011; Blangy \& Nielsen, 1993; Bramwell \& Lane, 1993). Interpretation can indeed reduce impacts, but only if stringent conditions are met (Coghlan \& Gooch, 2011; Littlefair \& Buckley, 2008). Otherwise, interpretation does not change either attitudes (Tubb, 2003) or impacts (Boon, Fluker, \& Wilson, 2008; Littlefair \& Buckley, 2008). 
Tourism can support conservation through private reserves, communal conservancies, and contributions to public protected areas, but only under some circumstances, and with associated environmental costs (Balmford et al., 2009; Buckley, 2009c, 2010; Buckley, 2011a). In some countries, over 50\% of parks funding is now derived from visitor fees, though more typically it is around $10 \%$ and in many countries, $0 \%$. Leasing tourism operating rights on communal land tenures may or may not contribute to community wellbeing and biodiversity conservation, depending on the legal details of land and wildlife ownership and the structure, cohesion and internal governance of community organisations (Akyeampong, 2011; Buckley, 2008b, 2010, 2011a; Jamal \& Stronza, 2009; Meguro \& Inoue, 2011; Saarinen et al., 2009; Stronza \& Durham, 2008). Similar considerations apply where tour operators lease rights from private landowners or land trusts (Buckley, 2010; Chancellor, Norman, Farmer, \& Coe, 2011) or from public national parks (Barborak, 2011; Buckley, 2010; Bushell \& Eagles, 2007; Svensson, Rodwell, \& Attrill, 2009).

The significance of sustainability indicators in tourism is long recognised (Butler, 1991). Many have been proposed (Castellani \& Sala, 2010; Ko, 2005; McCool, Moisey, \& Nickerson, 2001; Miller, 2001; Roberts \& Tribe, 2008; Tsaur, Lin, \& Lin, 2006). Few of these address actual impacts (Hughes, 2002), reflecting scarcity of ecological data (Buckley, 2004, 2011a). Indicators based solely on tourist, resident or operator perceptions may be incomplete, since people may not always perceive, understand or care about their impacts (Budeanu, 2007; Dodds, Graci, \& Holmes, 2010; Miller, Rathouse, Scarles, Holmes, \& Tribe, 2010; Puczko \& Ratz, 2000). There seems to be only one attempt to quantify any sustainability indicator for the tourism sector worldwide, focussing on pollution (Gössling, 2002). Such limited progress applies in all sectors, not only tourism (Bohringer \& Jochem, 2007).

Comparing the tourism research literature against the sustainability framework yields a number of broad-scale conclusions. A single quantitative measure of sustainability in tourism remains elusive, because of difficulties in: definition, what to include; accounting, comparing different impacts in commensurate terms (Buckley, 2009b); and analysis, tracking social and political mechanisms (Honey, 1999). Despite these uncertainties, it is clear that mainstream tourism, like other industry sectors and the human economy as a whole, is far from sustainable. Most tourism enterprises adopt only those practices that improve profits or public 
relations (Lane, 2009; Sheldon \& Park, 2011; Weaver, 2009). Improvements are driven principally by regulatory changes, often against political resistance and with poor implementation. Market measures are largely ineffective, with little direct public demand for sustainability in tourism (Budeanu, 2007; Miller et al., 2010; Weaver, 2009). Tourists expect operators to minimise impacts routinely, not as a criterion on which to choose between competing providers (Mair \& Jago, 2010).

Currently, there are few individual commercial tourism enterprises with positive triple bottom lines, including positive net contributions to local communities and to conservation (Buckley, 2009b, 2010). There are rather more which take voluntary measures to reduce environmental impacts, and make voluntary contributions to community wellbeing. The vast majority take such measures only for legal compliance or cost cutting. Tourism industry advocates lobby against government environmental regulation, proposing self-regulation as an alternative. They also lobby constantly for property development, tour operation and visitor management rights inside public protected areas, all with generally negative consequences for parks and biodiversity conservation.

To improve social and environmental performance across the entire tourism sector, both innovation and adoption are critical. Tourism enterprises often lead new approaches, but mainstreaming needs government legislation: self-regulation and ecocertification are ineffective. Improved sustainability in urban hotels, for example, has been driven by regulations for planning, impact assessment, pollution control, biodiversity and heritage conservation, building construction, energy and water efficiency, recycling, and so on. Voluntary private initiatives contribute principally by leading regulatory change. There is thus no way to avoid the complexities of politics, legislative change, international trade barriers to domestic environmental law (Buckley, 1993), industry lobbying for selfregulation, misrepresentation in the mass media (Lane, 2009), and so on. There is no secret ingredient (Po, 2008).

In forecasting the future of sustainable tourism, the key consideration is that both tourism and sustainability are changing more rapidly than the tourism industry adopts sustainability improvements. The future of tourism depends largely on conflicting social and economic pressures. People want holidays, and on holiday they act hedonistically. The most populous nations are richer, so more people travel. Tourism industry associations promote growth. 
Even parks agencies promote tourism, despite impacts. Travel costs, however, are rising with oil prices (Becken \& Schiff, 2011). Governments adopt carbon taxes and trading systems which include tourism. Tourism destinations are affected by climate change, despite adaptation (Buckley, 2008b; Lemieux, Beechey, Scott, \& Gray, 2011). Amidst these pressures, large-scale voluntary improvements in sustainability are improbable, especially given low public pressure for sustainability and the particular ambivalence to tourism.

\section{CONCLUSIONS}

All five of the key themes identified earlier are critical to sustainability; but the influence of tourism, interest by the tourism industry, and research effort to date, differ between them (Table 1). Except for a few unusual enterprises (Buckley, 2010), the tourism industry focuses strongly on economic aspects, with attention to social and environmental aspects confined to legal compliance, political manoeuvring, and marketing and public relations (Buckley 2009b; Hall, 2010; Lane, 2009; Weaver, 2009). Tourism research in environmental journals addresses parks and pollution aspects, but few scientists study tourism (Buckley, 2011a). Peace and population issues are barely addressed (IIPT, 2011).

Research topics significant for sustainable tourism were identified several decades ago (Buckley, 1996; Cohen, 1978; May, 1991). These topics have changed little (Table 2), save for the addition of climate change. There has been extensive publication during this period, but progress has been mixed. In addition, much of the most relevant research is not in tourism journals. In its initial struggle to gain recognition as an independent discipline, tourism research became somewhat self-referential. It could now make greater use of related research in other fields. Cross-disciplinary publication is commonplace in tourism economics, and in tourism and climate change, but not in tourism and environmental management (Buckley, 2011a).

The tourism industry does not pay much direct attention to research (Buckley, 2008b; Lane, 2009). If academics can understand what the industry does and why, however, then that information contributes to government policy and regulation which improve sustainability. There is, however, a critical caveat. Whilst academics see information as having intrinsic value and incorruptible importance, most of the world sees information mainly as a means to gain power, fame or money. The products of research become tools of advocates, politicians 
and entrepreneurs, no matter how hard researchers strive to remain independent. This is particularly prevalent in contested domains such as sustainable tourism.

Sustainability is shorthand for human and planetary future, yet tourism research treats it as a small subdiscipline. Tourism journals routinely publish rankings of research outputs, yet only one such ranking includes sustainability (Park, Phillips, Canter, \& Abbott, 2011); and that is based only on publications in top-tier tourism and hospitality journals, ignoring other social, environmental and sustainability journals. Interest in sustainability amongst tourism researchers seems to be as limited as it is amongst tourism industry advocates, enterprises and tourists. Large-scale social and environmental changes are altering the world in which tourism operates, but few researchers are attempting to grapple with these changes.

With this in mind, Table 2 also attempts to pick some immediate priorities for future research. One longstanding concern (Butler, 1991; Butler, 1999) is to develop quantitative sustainability indicators for the tourism sector. The most difficult component is to establish environmental accounting measures, so this remains a priority for research. Measurement and management of all types of tourism impact remain important. One particular current priority, however, is the ability of tourism to bring about large-scale change in land use, by generating financial and political support for conservation. This is increasingly urgent as the world's nations attempt to increase their protected area estate from $10 \%$ to $17 \%$ of land area over the next decade, in line with the internationally agreed Aichi targets, as a buffer against climate change. Finally, responses to impacts continue to include regulatory, corporate and technological measures, but individual reactions to responsibility in light of global change seem to form a particularly promising field for future research.

Sustainability is as important in tourism as in any other sector of the human economy, and equally difficult to achieve (Casagrandi \& Rinaldi, 2002). As noted by Sharpley (2009), there is "limited evidence of its implementation in practice". As long as the language of international politics is couched in terms of sustainable development, however, then the terminology of sustainability, as well as the practicalities of social and environmental management, will remain critically important in tourism research as well as reality. This review identifies some immediate priorities for academic research aimed to improve the sustainability of the tourism industry in reality. 


\section{Acknowledgements}

I thank Professor John Tribe, Editor-in-Chief for Annals of Tourism Research, for the invitation to write this review; Professor David Weaver and Professor Stefan Gössling for constructive critiques of drafts; and colleagues worldwide for information, insights and inspiration over several decades of relevant research. Conclusions remain my own responsibility. 


\section{REFERENCES}

Aall, C. (2011). Energy use and leisure consumption in Norway: An analysis and reduction strategy. Journal of Sustainable Tourism, 19(6), 729-745.

Acevedo-Gutiérrez, A., Acevedo, L., \& Boren, L. (2011). Effects of the presence of officiallooking volunteers on harassment of New Zealand fur seals. Conservation Biology, 25(3), 623-627.

Ahn, B.-Y., Lee, B.-K., \& Shafer, C. S. (2002). Operationalizing sustainability in regional tourism planning: An application of the limits of acceptable change framework. Tourism Management, 23(1), 1-15.

Akyeampong, O. A. (2011). Pro-poor tourism: Residents' expectations, experiences and perceptions in the Kakum National Park area of Ghana. Journal of Sustainable Tourism, 19(2), 197-213.

Allen, L. R., Long, P. T., Perdue, R. R., \& Kieselbach, S. (1988). The impact of tourism development on residents' perceptions of community life. Journal of Travel Research, 27(1), $16-21$.

Alpizar, F. (2006). The pricing of protected areas in nature-based tourism: A local perspective. Ecological Economics, 56(2), 294-307.

Ayuso, S. (2007). Comparing voluntary policy instruments for sustainable tourism: The experience of the Spanish hotel sector. Journal of Sustainable Tourism, 1, 144-159.

Ballantyne, R., Packer, J., \& Hughes, K. (2009). Tourists' support for conservation messages and sustainable management practices in wildlife tourism experiences. Tourism Management, $30(5), 658-664$.

Ballantyne, R., Packer, J., \& Sutherland, L. A. (2011). Visitors' memories of wildlife tourism: Implications for the design of powerful interpretive experiences. Tourism 
Management, 32(4), 770-779.

Balmford, A., Beresford, J., Green, J., Naidoo, R., Walpole, M., \& Manica, A. (2009). A global perspective on trends in nature-based tourism. Plos Biology, 7(6), e1000144.

Barborak, J. (2011). Results of a comparative international review of public-private partnerships for tourism management in protected areas. Available from http://conserveonline.org/.

Becken, S., \& Patterson, M. (2006). Measuring national carbon dioxide emissions from tourism as a key step towards achieving sustainable tourism. Journal of Sustainable Tourism, 14(4), 323-338.

Becken, S., \& Schiff, A. (2011). Distance models for New Zealand international tourists and the role of transport prices. Journal of Travel Research, 50(3), 303-320.

Beder, S. (1997). Global spin. Melbourne: Scribe.

Berry, S., \& Ladkin, A. (1997). Sustainable tourism: A regional perspective. Tourism Management, 18(7), 433-440.

Black, R., \& Crabtree, A. (2007). Quality assurance and certification in ecotourism. Wallingford: $\mathrm{CAB}$ International.

Blanco, E., Lozano, J., \& Rey-Maquieira, J. (2009). A dynamic approach to voluntary environmental contributions in tourism. Ecological Economics, 69(1), 104-114.

Blangy, S., \& Nielsen, T. (1993). Ecotourism and minimum impact policy. Annals of Tourism Research, 20(2), 357-360.

Bohringer, C., \& Jochem, P. E. P. (2007). Measuring the immeasurable - A survey of sustainability indices. Ecological Economics, 63(1), 1-8.

Boon, P. I., Fluker, M., \& Wilson, N. (2008). Ten-year study of the effectiveness of an 
educative programme in ensuring the ecological sustainability of recreational activities in the Brisbane Ranges National Park, south-eastern Australia. Journal of Sustainable Tourism, 16(6), 681-697.

Bramwell, B., \& Lane, B. (1993). Interpretation and sustainable tourism: The potential and pitfalls. Journal of Sustainable Tourism, 1(2), 71-80.

Brougham, J. E., \& Butler, R. W. (1981). A segmentation analysis of residents' attitudes to the social impact of tourism. Annals of Tourism Research, 8(4), 569-590.

Buckley, R. C. (1993). International trade, investment and environment: An environmental management perspective. Journal of World Trade, 27(4), 102-148.

Buckley, R. C. (1996). Sustainable tourism: Technical issues and information needs. Annals of Tourism Research, 23, 925-928.

Buckley, R. C. (1998). Tools and indicators for managing tourism in parks. Annals of Tourism Research, 26, 207-210.

Buckley, R. C. (1999). An ecological perspective on carrying capacity. Annals of Tourism Research, 26, 705-708.

Buckley, R. C. (2002). Tourism ecolabels. Annals of Tourism Research, 29, 183-208.

Buckley, R. C. (2003a). Case studies in ecotourism. Wallingford: CAB International, 264 pp.

Buckley, R. C. (2003b). Pay to play in parks: An Australian policy perspective on visitor fees in public protected areas. Journal of Sustainable Tourism, 11, 56-73.

Buckley, R. C. (Ed.). (2004). Environmental impacts of ecotourism. CAB International: Wallingford, $389 \mathrm{pp}$.

Buckley, R. C. (2008a). Climate change: Tourism destination dynamics. Tourism Recreation Research, 33(3), 354-355. 
Buckley, R. C. (2008b). Testing take-up of academic concepts in an influential commercial tourism publication. Tourism Management, 29(4), 721-729.

Buckley, R. C. (2009a). Ecotourism: Principles and practices. Wallingford: CAB International, $368 \mathrm{pp}$.

Buckley, R. C. (2009b). Evaluating the net effects of ecotourism on the environment: A framework, first assessment and future research. Journal of Sustainable Tourism, 17(6), 643672.

Buckley, R. C. (2009c). Parks and tourism. PLoS Biology, 7(6), e1000143.

Buckley, R. C. (2010). Conservation tourism. Wallingford: CAB International, 214 pp.

Buckley, R. C. (2011a). Tourism and environment. Annual Review of Environment and Resources, 36. doi:10.1146/annurev-environ-041210-132637E.

Buckley, R. C. (2011b). 20 Answers: Reconciling air travel and climate change. Annals of Tourism Research, 38(3), 1178-1181.

Buckley, R. C., \& Pegas, F. (in press). Tourism and corporate social responsibility. In A. Holden, \& D. Fennell (Eds.), Handbook of tourism and environment. London: Routledge.

Buckley, R. C., \& Araujo, G. (1997). Environmental management performance in tourism accommodation. Annals of Tourism Research, 24, 465-469.

Budeanu, A. (2007). Sustainable tourist behaviour - A discussion of opportunities for change. International Journal of Consumer Studies, 31(5), 499-508.

Bushell, R., \& Eagles, P. F. J. (2007). Tourism and protected areas: Benefits beyond boundaries. Wallingford: CAB International.

Butler, R. (1991). Tourism, environment, and sustainable development. Environmental 
Conservation, 18(3), 201-209.

Butler, R. (1999). Sustainable tourism: A state-of-the-art review. Tourism Geographies, 1(1), $7-25$.

Casagrandi, R., \& Rinaldi, S. (2002). A theoretical approach to tourism sustainability. Conservation Ecology, 6(1), 13. http://www.consecol.org/vol6/iss1/art13/.

Castellani, V., \& Sala, S. (2010). Sustainable performance index for tourism policy development. Tourism Management, 31(6), 871-880.

Cater, E. (1987). Tourism in the least developed countries. Annals of Tourism Research, 14(2), 202-226.

Chan, W. W., \& Lam, J. C. (2003). Energy-saving supporting tourism sustainability: A case study of hotel swimming pool heat pump. Journal of Sustainable Tourism, 11(1), 74-83.

Chancellor, C., Norman, W., Farmer, J., \& Coe, E. (2011). Tourism organizations and land trusts: A sustainable approach to natural resource conservation?. Journal of Sustainable Tourism, 19(7), 863-875.

Charara, N., Cashman, A., Bonnell, R., \& Gehr, R. (2011). Water use efficiency in the hotel sector of Barbados. Journal of Sustainable Tourism, 19(2), 231-245.

Choi, H. C., \& Murray, I. (2010). Resident attitudes towards sustainable community tourism. Journal of Sustainable Tourism, 18(4), 575-594.

Choo, H. (2011). Marketing innovations for sustainable destinations. Tourism Management, 32(4), 959-960.

Chung, J. Y., Kyle, G. T., Petrick, J. F., \& Absher, J. D. (2011). Fairness of prices, user fee policy and willingness to pay among visitors to a national forest. Tourism Management, $32(5), 1038-1046$. 
CIRET (2012). Encyclopedie de la recherche touristique mondiale. Paris: Centre Internationale de Recherches et d'Etudes Touristiques.

Clarke, J. (1997). A framework of approaches to sustainable tourism. Journal of Sustainable Tourism, 5(3), 224-233.

Claver-Cortes, E., Molina-Azoin, J., Pereira-Moliner, J., \& Lopez-Gamero, M. D. (2007). Environmental strategies and their impact on hotel performance. Journal of Sustainable Tourism, 15(6), 663-679.

Coccossis, H., \& Nijkamp, P. (1995). Sustainable tourism development. Michigan: Avebury.

Coghlan, A., \& Gooch, M. (2011). Applying a transformative learning framework to volunteer tourism. Journal of Sustainable Tourism, 19(6), 713-728.

Cohen, E. (1978). The impact of tourism on the physical environment. Annals of Tourism Research, 5(2), 215-237.

Cohen, S. A., \& Higham, J. E. S. (2011). Eyes wide shut? UK consumer perceptions on aviation climate impacts and travel decisions to New Zealand. Current Issues in Tourism, 14(4), 323-335.

Cole, S. (2006). Information and empowerment: The keys to achieving sustainable tourism. Journal of Sustainable Tourism, 14(6), 629-644.

Crompton, J. L. (2011). A theoretical framework for formulating non-controversial prices for public park and recreation services. Journal of Leisure Research, 43(1), 1-29.

Cummings, L. E. (1997). Waste minimisation supporting urban tourism sustainability: A mega-resort case study. Journal of Sustainable Tourism, 5(2), 93-108.

Cunha, A. A. (2010). Negative effects of tourism in a Brazilian Atlantic forest national park. Journal for Nature Conservation, 18(4), 291-295. 
Davis, J. S., \& Morais, D. B. (2004). Factions and enclaves: Small towns and socially unsustainable tourism development. Journal of Travel Research, 43(1), 3-11.

Dickinson, J. E., \& Dickinson, J. A. (2006). Local transport and social representations: Challenging the assumptions for sustainable tourism. Journal of Sustainable Tourism, 14(2), 192-208.

Dinica, V. (2009). Governance for sustainable tourism: A comparison of international and Dutch visions. Journal of Sustainable Tourism, 17(5), 583-603.

Dodds, R., Graci, S. R., \& Holmes, M. (2010). Does the tourist care? A comparison of tourists in Koh Phi Phi, Thailand and Gili Trawangan, Indonesia. Journal of Sustainable Tourism, 18(2), 207-222.

Driml, S., \& Common, M. (1996). Ecological economics criteria for sustainable tourism: Application to the Great Barrier Reef and Wet Tropics World Heritage Areas, Australia. Journal of Sustainable Tourism, 4(1), 3-16.

Dubois, G., \& Ceron, J.-P. (2006). Tourism and climate change: Proposals for a research agenda. Journal of Sustainable Tourism, 14(4), 399-415.

Eagles, P. F. J., McCool, S. F., \& Haynes, C. D. (2002). Sustainable tourism in protected areas: Guidelines for planning and management. Gland: IUCN.

Erkus-Ozturk, H., \& Eraydln, A. (2010). Environmental governance for sustainable tourism development: Collaborative networks and organisation building in the Antalya tourism region. Tourism Management, 31(1), 113-124.

Fallon, L. D., \& Kriwoken, L. K. (2003). Community involvement in tourism infrastructure The case of the Strahan Visitor Centre, Tasmania. Tourism Management, 24(3), 289-308.

Farrell, B., \& McLellan, R. (1987). Tourism and physical environment research. Annals of Tourism Research, 14(1), 1-16. 
Farrelly, T. A. (2011). Indigenous and democratic decision-making: Issues from communitybased ecotourism in the Bouma National Heritage Park, Fiji. Journal of Sustainable Tourism, 19(7), 817-835.

Ferhan, G. (2006). Components of sustainability: Two cases from Turkey. Annals of Tourism Research, 33(2), 442-455.

Font, X., \& Buckley, R. C. (Eds.). (2001). Tourism ecolabelling. Wallingford: CAB International, $359 \mathrm{pp}$.

Forsyth, T. (1997). Environmental responsibility and business regulation: The case of sustainable tourism. The Geographical Journal, 163(3), 270-280.

Garrod, B., \& Fyall, A. (1998). Beyond the rhetoric of sustainable tourism? Tourism Management, 19(3), 199-212.

Getz, D. (1986). Tourism and population change: Long-term impacts of tourism in the Badenoch and Strathspey District of the Scottish Highlands. Scottish Geographical Journal, 102(2), 113-126.

Ghali, M. A. (1976). Tourism and economic growth: An empirical study. Economic Development and Cultural Change, 24(3), 527-538.

Gill, A., \& Williams, P. (1994). Managing growth in mountain tourism communities. Tourism Management, 15, 212-220.

Glomsrød, S., Wei, T., Liu, G., \& Aune, J. B. (2011). How well do tree plantations comply with the twin targets of the Clean Development Mechanism? - The case of tree plantations in Tanzania. Ecological Economics, 70(6), 1066-1074.

Godfrey, K. B. (1995). Planning for sustainable tourism development in the Med. Tourism Management, 16(3), 243-245.

Gössling, S. (2000). Sustainable tourism development in developing countries: Some aspects 
of energy use. Journal of Sustainable Tourism, 8(5), 410-425.

Gössling, S. (2002). Global environmental consequences of tourism. Global Environmental Change, 12, 283-302.

Gössling, S. (2009). Carbon neutral destinations: A conceptual analysis. Journal of Sustainable Tourism, 17(1), 17-37.

Gössling, S. (2010). Carbon management in tourism. London: Routledge, 272 pp.

Gössling, S., Broderick, J., Upham, P., Ceron, J.-P., Dubois, G., Peeters, P., \& Strasdas, W. (2007). Voluntary carbon offsetting schemes for aviation: Efficiency, credibility and sustainable tourism. Journal of Sustainable Tourism, 15(3), 223-248.

Gössling, S., \& Hultman, J. (2006). Ecotourism in Scandinavia: Lessons in theory and practice. Wallingford: $\mathrm{CAB}$ International.

Gössling, S., \& Peeters, P. (2007). "It does not harm the environment!" An analysis of industry discourses on tourism, air travel and the environment. Journal of Sustainable Tourism, 15(4), 402-417.

Gössling, S., Peeters, P., Hall, C. M., Ceron, J.-P., Dubois, G., Lehman, L. V., \& Scott, D. (2011). Tourism and water use: Supply, demand and security, and international review. Tourism Management, 33(1), 16-28.

Gössling, S., \& Schumacher, K. P. (2010). Implementing carbon neutral destination policies: Issues from the Seychelles. Journal of Sustainable Tourism, 18(3), 377-391.

Halfwerk, W., Holleman, L. J. M., Lessells, C. M., \& Slabbekoorn, H. (2011). Negative impact of traffic noise on avian reproductive success. Journal of Applied Ecology, 48, 210219.

Hall, M. (2010). Changing paradigms and global change: From sustainable to steady-state tourism. Tourism Recreation Research, 35(2), 131-143. 
Hall, C. M., \& Butler, R. W. (1995). In search for common ground: Reflections on sustainability, complexity and process in the tourism system. Journal of Sustainable Tourism, 3(2), 99-105.

Hall, C. M., \& Lew, A. A. (1998). Sustainable tourism: A geographical perspective. Harlow: Longman.

Hall, M., \& Wouters, M. (1994). Managing nature tourism in the Sub-Antarctic. Annals of Tourism Research, 21(2), 355-374.

Hamilton, J. M., Maddison, D. J., \& Tol, R. S. J. (2005). Effects of climate change on international travel. Climate Research, 29, 245-254.

Hares, A., Dickinson, J., \& Wilkes, K. (2010). Climate change and the air travel decisions of UK tourists. Journal of Transport Geography, 18(3), 466-473.

Heberlein, T. A., Fredman, P., \& Vuorio, T. (2002). Current tourism patterns in the Swedish mountain region. Mountain Research and Development, 22(2), 142-149.

Hemson, G., Maclennan, S., Mills, G., Johnson, P., \& Macdonald, D. (2009). Community, lions, livestock and money: A spatial and social analysis of attitudes to wildlife and the conservation value of tourism in a human-carnivore conflict in Botswana. Biological Conservation, 142(11), 2718-2725.

Higham, J. E. S., \& Shelton, E. J. (2011). Tourism and wildlife habituation: Reduced population fitness or cessation of impact?. Tourism Management, 32(6), 1290-1298.

Honey, M. (1999). Ecotourism and sustainable development. Washington DC: Island.

Hritz, N., \& Cecil, A. K. (2008). Investigating the sustainability of cruise tourism: A case study of Key West. Journal of Sustainable Tourism, 16(2), 168-181.

Huang, B., Lubarsky, K., Teng, T., \& Blumstein, D. T. (2011). Take only pictures, leave only 
... fear? The effects of photography on the West Indian anole. Current Zoology, 57(1), 77-82.

Hughes, G. (1995). The cultural construction of sustainable tourism. Tourism Management, 16(1), 49-59.

Hughes, G. (2002). Environmental indicators. Annals of Tourism Research, 29(2), 457-477.

Hunter, C. (1997). Sustainable tourism as an adaptive paradigm. Annals of Tourism Research, 24(4), 850-867.

Hunter, C., \& Shaw, J. (2007). The ecological footprint as a key indicator of sustainable tourism. Tourism Management, 28(1), 46-57.

International Institute for Peace through Tourism (2011). International Institute for Peace through Tourism. Available from http://www.iipt.org/.

Ioannides, D. (1995). A flawed implementation of sustainable tourism: The experience of Akamas, Cyprus. Tourism Management, 16(8), 583-592.

Jamal, T., \& Stronza, A. (2009). Collaboration theory and tourism practice in protected areas: Stakeholders, structuring and sustainability. Journal of Sustainable Tourism, 17(2), 169-189.

Kaltenborn, B. P., Haaland, H., \& Sandell, K. (2001). The public right of access - Some challenges to sustainable tourism development in Scandinavia. Journal of Sustainable Tourism, 9(5), 417-433.

Kastenholz, E. (2004). 'Management of demand' as a tool in sustainable tourist destination development. Journal of Sustainable Tourism, 12(5), 388-408.

Ko, T. G. (2005). Development of a tourism sustainability assessment procedure: A conceptual approach. Tourism Management, 26(3), 431-445.

Kociolek, A. V., Clevenger, A. P., St. Clair, C. C., \& Proppe, D. S. (2011). Effects of road networks on bird populations. Conservation Biology, 25(2), 241-249. 
Lane, B. (2009). Thirty years of sustainable tourism. In S. Gössling, C. M. Hall, \& D. B. Weaver (Eds.), Sustainable tourism futures (pp. 19-32). New York: Routledge.

Larson, S., Brun, W., Ogaard, T., \& Selstad, L. (2011). The effects of sudden and dramatic events on travel desire and risk judgements. Scandinavian Journal of Hospitality and Tourism, 11(3), 268-285.

Lawton, L. J., \& Weaver, D. B. (2010). Normative and innovative sustainable resource management at birding festivals. Tourism Management, 31(4), 527-536.

Lemieux, C. J., Beechey, T. J., Scott, D. J., \& Gray, P. A. (2011). The state of climate change adaptation in Canada's protected areas sector. Canadian Geographer, 55(3), 301-317.

Lian, X., Zhang, T., Cao, Y., Su, J., \& Thirgood, S. (2011). Road proximity and traffic flow perceived as potential predation risks: Evidence from the Tibetan antelope in the Kekexili National Nature Reserve, China. Wildlife Research, 38(2), 141-146.

Liddle, M. J. (1997). Recreation ecology: The ecological impact of outdoor recreation. Dordrecht: Kluwer Academic Publishers.

Lindberg, K., McCool, S., \& Stankey, G. (1997). Rethinking carrying capacity. Annals of Tourism Research, 24(2), 461-465.

Littlefair, C., \& Buckley, R. C. (2008). Interpretation reduces ecological impacts of visitors to World Heritage Areas. Ambio, 37(5), 338-341.

Liu, Z. (2003). Sustainable tourism development: A critique. Journal of Sustainable Tourism, $11(6), 459-475$.

Liu, J. C., \& Var, T. (1986). Resident attitudes toward tourism impacts in Hawaii. Annals of Tourism Research, 13(2), 193-214.

Llorca-Vivero, R. (2008). Terrorism and international tourism: New evidence. Defence and 
Peace Economics, 19, 169-188.

Logar, I. (2010). Sustainable tourism management in Crikvenica, Croatia: An assessment of policy instruments. Tourism Management, 31(1), 125-135.

Mair, J., \& Jago, L. (2010). The development of a conceptual model of greening in the business events tourism sector. Journal of Sustainable Tourism, 18(1), 77-94.

Manyara, G., \& Jones, E. (2007). Community-based tourism enterprises development in Kenya: An exploration of their potential as avenues of poverty reduction. Journal of Sustainable Tourism, 15(6), 628-644.

Maréchal, L., Semple, S., Majolo, B., Qarro, M., Heistermann, M., \& MacLarnon, A. (2011). Impacts of tourism on anxiety and physiological stress levels in wild male Barbary macaques. Biological Conservation, 144(9), 2188-2193.

Martin-Cejas, R., \& Sanchez, P. (2010). Ecological footprint analysis of road transport related to tourism activity: The case for Lanzarote Island. Tourism Management, 31(1), 98103.

Matarrita-Cascante, D., Brennan, M. A., \& Luloff, A. E. (2010). Community agency and sustainable tourism development: The case of La Fortuna, Costa Rica. Journal of Sustainable Tourism, 18(6), 735-756.

May, V. (1991). Tourism, environment and development - Values, sustainability and stewardship. Tourism Management, 12(2), 112-124.

Mbaiwa, J. E. (2011). Changes on traditional livelihood activities and lifestyles caused by tourism development in the Okavango Delta, Botswana. Tourism Management, 32(5), 10501060. doi:10.1016/j.tourman.2010.09.002.

Mbaiwa, J. E., \& Stronza, A. L. (2010). The effects of tourism development on rural livelihoods in the Okavango Delta, Botswana. Journal of Sustainable Tourism, 18(5), 635656. 
McCool, S., \& Moisey, R. (2001). Tourism, recreation and sustainability: Linking culture and the environment. New York: CABI Publishing.

McCool, S. F., Moisey, R. N., \& Nickerson, N. P. (2001). What should tourism sustain? The disconnect with industry perceptions of useful indicators. Journal of Travel Research, 40(2), 124-132.

McCool, S. F., \& Stankey, G. H. (2001). Managing access to wildlands for recreation in the USA: Background and issues relevant to sustainable tourism. Journal of Sustainable Tourism, 9(5), 389-399.

McKenna, J., Williams, A. T., \& Cooper, J. A. G. (2011). Blue flag or red herring: Do beach awards encourage the public to visit beaches?. Tourism Management, 32(3), 576-588.

Meguro, T., \& Inoue, M. (2011). Conservation goals betrayed by the uses of wildlife benefits in community-based conservation: The Case of Kimana Sanctuary in southern Kenya. Human Dimensions of Wildlife, 16(1), 30-44.

Mendes, L. M. Z., \& Santos, G. (2008). Using economic instruments to address emissions from air transport in the European Union. Environment and Planning A, 40(1), 189-209.

Miller, G. (2001). The development of indicators for sustainable tourism: Results of a Delphi survey of tourism researchers. Tourism Management, 22(4), 351-362.

Miller, G., Rathouse, K., Scarles, C., Holmes, K., \& Tribe, J. (2010). Public understanding of sustainable tourism. Annals of Tourism Research, 37(3), 627-645.

Mmopelwa, G., Kgathi, D. L., \& Molefhe, L. (2007). Tourists' perceptions and their willingness to pay for park fees: A case study of self-drive tourists and clients for mobile tour operators in Moremi Game Reserve, Botswana. Tourism Management, 28(4), 1044-1056.

Moore, S. A., \& Rodger, K. (2010). Wildlife tourism as a common pool resource issue: Enabling conditions for sustainability governance. Journal of Sustainable Tourism, 18(7), 
$831-844$.

Mycoo, M. (2006). Sustainable tourism using regulations, market mechanisms and green certification: A case study of Barbados. Journal of Sustainable Tourism, 14(5), 489-511.

Nash, D., \& Butler, R. (1990). Towards sustainable tourism. Tourism Management, 11(3), 263-264.

Naughton-Treves, L., Holland, M. B., \& Brandon, K. (2005). The role of protected areas in conserving biodiversity and sustaining local livelihoods. Annual Review of Environment and Resources, 30(1), 219-252.

Nelson, F. (2010). Community rights, conservation and contested land: The politics of natural resource governance in Africa. London: Earthscan, 342 pp.

Neumayer, E. (2004). The impact of political violence on tourism. Journal of Conflict Resolution, 48, 259-281.

Nimon, A. J., Schroter, R. C., \& Stonehouse, B. (1995). Heart rate of disturbed penguins. Nature, 374(6521), 415.

Nunez, J. (2007). Can self regulation work? A story of corruption, impunity and cover-up. Journal of Regulatory Economics, 31, 209-233.

Okazaki, E. (2008). A community-based tourism model: Its conception and use. Journal of Sustainable Tourism, 16(5), 511-529.

Owen, R. E., Witt, S. F., \& Gammon, S. (1993). Sustainable tourism development in Wales: From theory to practice. Tourism Management, 14(6), 463-474.

Park, E., \& Boo, S. (2010). An assessment of convention tourism's potential contribution to environmentally sustainable growth. Journal of Sustainable Tourism, 18(1), 95-113.

Park, K., Phillips, J. W. M., Canter, D. D., \& Abbott, J. A. (2011). Hospitality and tourism 
research rankings by author, university, and country using six major journals: The first decade of the new millennium. Journal of Hospitality and Tourism Research, 35(3), 381-416.

Pereira, H. M., Leadley, P. W., Proença, V., Alkemade, R., \& Scharlemann, J. P. W. (2010). Scenarios for global biodiversity in the 21 st century. Science, 330, 1496-1501.

Perry, A. (2006). Will predicted climate change compromise the sustainability of Mediterranean tourism?. Journal of Sustainable Tourism, 14(4), 367-375.

Persha, L., Agrawal, A., \& Chhatre, A. (2011). Social and ecological synergy. Science, 331, 1606-1608.

Peters, H., \& Hawkins, J. P. (2009). Access to marine parks: A comparative study in willingness to pay. Ocean and Coastal Management, 52(3-4), 219-228.

Pickering, C., \& Buckley, R. C. (2010). Climate response by the ski industry: The shortcomings of snowmaking for Australian resorts. Ambio, 39(5-6), 430-438.

Po, P. (2008). In DreamWorks Animation, Kung fu panda. Hollywood: Paramount Pictures.

Priego, M. J., Najera, J. J., \& Font, X. (2011). Environmental management decision-making in certified hotels. Journal of Sustainable Tourism, 19(3), 361-381.

Priego, M. J., Najera, J. J., \& Font, X. (2011). Environmental management decision-making in certified hotels. Journal of Sustainable Tourism, 19(3), 361-381.

Puczko, L., \& Ratz, T. (2000). Tourist and resident perceptions of the physical impacts of tourism at Lake Balaton, Hungary: Issues for sustainable tourism management. Journal of Sustainable Tourism, 8(6), 458-478.

Reed, S. E., \& Merenlender, A. M. (2011). Effects of management of domestic dogs and recreation on carnivores in protected areas in northern California. Conservation Biology, 25, 504-513. 
Remacha, C., Pérez-Tris, J., \& Delgado, J. A. (2011). Reducing visitors' group size increases the number of birds during educational activities: Implications for management of naturebased recreation. Journal of Environmental Management, 92(6), 1564-1568.

Reynisdottir, M., Song, H., \& Agrusa, J. (2008). Willingness to pay entrance fees to natural attractions: An Icelandic case study. Tourism Management, 29(6), 1076-1083.

Roberts, S., \& Tribe, J. (2008). Sustainability indicators for small tourism enterprises - An exploratory perspective. Journal of Sustainable Tourism, 16(5), 575-594.

Robinson, M. (1999). Collaboration and cultural consent: Refocusing sustainable tourism. Journal of Sustainable Tourism, 7(3-4), 379-397.

Roux-Fouillet, P., Wipf, S., \& Rixen, C. (2011). Long-term impacts of ski piste management on alpine vegetation and soils. Journal of Applied Ecology, 48(4), 906-915.

Saarinen, J. (2006). Traditions of sustainability in tourism studies. Annals of Tourism Research, 33(4), 1121-1140.

Saarinen, J., Becker, F., Manwa, H., \& Wilson, D. (Eds.). (2009). Sustainable tourism in Southern Africa: Local communities and natural resources in transition. Bristol: Channel View Publications.

Scott, D. (2011). Why sustainable tourism must address climate change. Journal of Sustainable Tourism, 19(1), 17-34.

Scott, D., McBoyle, G., Minogue, A., \& Mills, B. (2006). Climate change and the sustainability of ski-based tourism in eastern North America: A reassessment. Journal of Sustainable Tourism, 14, 376-398.

Sharpley, R. (2000). Tourism and sustainable development: Exploring the theoretical divide. Tourism of Sustainable Tourism, 8(1), 1-19.

Sharpley (2009). Tourism development and the environment: beyond sustainability? London: 
Earthscan, $220 \mathrm{pp}$.

Sheldon, P. J., \& Park, S.-Y. (2011). An exploratory study of corporate social responsibility in the US travel industry. Journal of Travel Research, 50(4), 392-407.

Shultis, J., \& More, T. (2011). American and Canadian national park agency responses to declining visitation. Journal of Leisure Research, 43(1), 110-132.

Smerecnik, K. O., \& Andersen, P. A. (2011). The diffusion of environmental sustainability innovations in North American hotels and ski resorts. Journal of Sustainable Tourism, 19(2), 171-196.

Smith, V. (1977). Hosts and guests: The anthropology of tourism. Philadelphia: University of Pennsylvania.

Somanathan, E., Prabhakar, R., \& Mehta, B. S. (2009). Decentralization for cost-effective conservation. Proceedings of the National Academy of Sciences, 106(11), 4143-4147.

Soteriou, E. C., \& Coccossis, H. (2010). Integrating sustainability into the strategic planning of national tourism organisations. Journal of Travel Research, 49(2), 191-205.

Spenceley, A. (2008). Responsible tourism: Critical issues for conservation and development. London: Earthscan, 432 pp.

Spillerman, S., \& Stecklov, G. (2009). Societal responses to terrorist attacks. Annual Review of Sociology, 35, 167-189.

Stabler, M. (1997). Tourism and sustainability: Principles to practice. Wallingford: CAB International.

Steven, R., Pickering, C., \& Castley, J. G. (2011). A review of the impacts of nature-based recreation on birds. Journal of Environmental Management, 92(10), 2287-2294. doi:10.1016/j.jenvman.2011.05.005. 
Stronza, A. (2001). Anthropology of tourism: Forging new ground for ecotourism and other alternatives. Annual Review of Anthropology, 30, 261-284.

Stronza, A., \& Durham, W. H. (Eds.). (2008). Ecotourism and conservation in the Americas. Wallingford: CAB International.

Stronza, A., \& Gordillo, J. (2008). Community views of ecotourism: Redefining benefits. Annals of Tourism Research, 35(2), 444-468.

Svensson, P., Rodwell, L. D., \& Attrill, M. J. (2009). Privately managed marine reserves as a mechanism for the conservation of coral reef ecosystems: A case study from Vietnam. Ambio, 38(2), 72-78.

Swarbrooke, J. (1999). Sustainable tourism management. Wallingford: CAB International.

Thur, M. T. (2010). User fees as sustainable financing mechanisms for marine protected areas: An application to the Bonaire National Marine Park. Marine Policy, 34(1), 63-69.

Tosun, C. (2001). Challenges of sustainable tourism development in the developing world: The case of Turkey. Tourism Management, 22(3), 289-303.

Tsaur, S.-H., Lin, Y.-C., \& Lin, J.-H. (2006). Evaluating ecotourism sustainability from the integrated perspective of resource, community and tourism. Tourism Management, 27(4), 640-653.

Tubb, K. N. (2003). An evaluation of the effectiveness of interpretation within Dartmoor National Park in reaching the goals of sustainable tourism development. Journal of Sustainable Tourism, 11(6), 476-498.

Tucker, H. (2001). Tourists and troglodytes: Negotiating for sustainability. Annals of Tourism Research, 28(4), 868-891.

Turner, L., \& Ash, J. (1975). The golden hordes: International tourism and the pleasure periphery. London: Constable. 
Uyarra, M., Gill, J., \& Côté, I. (2010). Charging for nature: Marine park fees and management from a user perspective. Ambio, 39(7), 515-523.

Velando, A., \& Munilla, I. (2011). Disturbance to a foraging seabird by sea-based tourism: Implications for reserve management in marine protected areas. Biological Conservation, 144(3), 1167-1174.

Verbeek, D., \& Mommaas, H. (2008). Transitions to sustainable tourism mobility: The social practices approach. Journal of Sustainable Tourism, 16(6), 629-644.

Wagner, G. (2011). Going green but getting nowhere. New York Times, A29.

Wall, G. (1993). International collaboration in the search for sustainable tourism in Bali, Indonesia. Journal of Sustainable Tourism, 1(1), 38-47.

Wang, Z., Li, Z., Beauchamp, G., \& Jiang, Z. (2011). Flock size and human disturbance affect vigilance of endangered red-crowned cranes. Biological Conservation, 144(1), 101105.

Warnken, J., \& Buckley, R. C. (1998). Scientific quality of tourism EIA. Journal of Applied Ecology, 35, 1-8.

Wearing, S. L., Wearing, M., \& McDonald, M. (2010). Understanding local power and interactional processes in sustainable tourism: Exploring village-tour operator relations on the Kokoda Track, Papua New Guinea. Journal of Sustainable Tourism, 18(1), 61-76.

Weaver, D. (2010). Indigenous tourism stages and their implications for sustainability. Journal of Sustainable Tourism, 18(1), 43-60.

Weaver, D. (2011). Can sustainable tourism survive climate change?. Journal of Sustainable Tourism, 19(1), 5-15.

Weaver, D. (2009). Reflections on sustainable tourism and paradigm change. In S. Gössling, 
C. M. Hall, \& D. B. Weaver (Eds.), Sustainable tourism futures (pp. 33-40). New York: Routledge.

Wilson, C., \& Tisdell, C. A. (2001). Sea turtles as a non-consumptive tourism resource especially in Australia. Tourism Management, 22(3), 279-288.

Wittemeyer, G., Elsen, P., Bean, W. T., Burton, A. C. O., \& Brashares, J. S. (2008). Accelerated human population growth at protected area edges. Science, 321, 123-126.

Yasarata, M., Altinay, L., Burns, P., \& Okumus, F. (2010). Politics and sustainable tourism development - Can they co-exist? Voices from North Cyprus. Tourism Management, 31(3), 345-356.

Young, G. (1973). Tourism - Blessing or blight?. London: Penguin.

Yu, C.-P., Chancellor, H. C., \& Cole, S. T. (2011). Measuring residents' attitudes towards sustainable tourism: A reexamination of the sustainable tourism attitude scale. Journal of Travel Research, 50(1), 57-63.

Zeppel, H. (2006). Indigenous ecotourism: Sustainable development and management. Wallingford: CAB International, $308 \mathrm{pp}$.

Zhong, L., Deng, J., Song, Z., \& Ding, P. (2011). Research on environmental impacts of tourism in China: Progress and prospect. Journal of Environmental Management, 92(11), 2972-2983.

Zubair, S., Bowen, D., \& Elwin, J. (2010).Not quite paradise: Inadequacies of environmental impact assessment in the Maldives. Tourism Management, 32(2), 225-234. 
Table 1. Sustainability Significance, Industry Influence and Research Effort

\begin{tabular}{llllll}
\hline & $\begin{array}{l}\text { Parks, } \\
\text { biodiversity, } \\
\text { conservation }\end{array}$ & $\begin{array}{l}\text { Pollution, } \\
\text { climate } \\
\text { change }\end{array}$ & $\begin{array}{l}\text { Prosperity, } \\
\text { poverty } \\
\text { alleviation }\end{array}$ & $\begin{array}{l}\text { Peace, } \\
\text { security, } \\
\text { safety }\end{array}$ & $\begin{array}{l}\text { Population } \\
\text { stabilisation } \\
\text { \& reduction }\end{array}$ \\
\hline $\begin{array}{l}\text { Significance for } \\
\text { sustainability }\end{array}$ & $* * * * *$ & $* * * * *$ & $* * * * *$ & $* * * * *$ & $* * * * *$ \\
$\begin{array}{l}\text { Influence of } \\
\text { tourism sector }\end{array}$ & $* * * * *$ & $* * * *$ & $* * *$ & $* *$ & $*$ \\
$\begin{array}{l}\text { Attention by } \\
\text { tourism industry }\end{array}$ & $* *$ & $* * *$ & $* * * * *$ & $* *$ & - \\
$\begin{array}{l}\text { Effort by tourism } \\
\text { researchers }\end{array}$ & $*$ & $* * * * * *$ & $*$ & $*$ \\
$\begin{array}{l}\text { Effort by science } \\
\text { researchers }\end{array}$ & $* * *$ & $* * * *$ & $*$ & - \\
\hline
\end{tabular}

Key: Number of stars indicates the scale or importance of factors in each row, for the components in each column. *****, most; *, least; -, none or negligible. 
Table 2. Issues in Sustainable Tourism Research and Practice

Issue Fields and topics

Practical Research Research interest progress priority

\section{$\operatorname{IMPACTS}(+\&-)$}

Site-scale, social \& Park management, recreation

ecological

ecology, cultural and

community change

Land-use change

Parks politics, conservation

agreements, private and

community reserves

Resource

consumption:

general

specific

Wastes and

pollution

Climate change

Energy and water conservation

Rare species used for souvenirs etc

High

Med High

$* *$

Water chemistry, microbiology

Low

Med

$*$

Med

Climatology, climate impacts

Med

Low

$* *$

RESPONSES

Individual

Cultural contexts, values,

High Low $* * *$

Social, government

behaviours, responsibility

Social, corporate

Policy, planning, EIA, legislation

Med Med

$* *$

Self-regulation, certification,

(de)marketing

Technological

Energy, water, materials

High

High

*

conservation, waste

High High *

treatment, recycling

\section{INDICATORS}

Economic

Social

Regional economies, poverty

High

High

High High

$*$

Net gains, equity, welfare

High

Low

$* *$

Lack of data,

incommensurable

parameters

Sustainability

Scope and definitions,

Low

Low

$* *$ (combined) incommensurable parameters

Research priorities: *, lowest; ***, highest. Priorities reflect degree of prior research effort as well as significance of topic for sustainable tourism. 